\title{
Mobilization of funds in Indonesian regional banking
}

\author{
Sapto Jumono ${ }^{a^{*}, \text { Sugiyanto }^{a} \text { and Chajar Matari Fath Mala }}{ }^{a}$
}

\begin{tabular}{l}
${ }^{a}$ Esa Unggul University, Economic Fach \\
\hline C H R O N I C L E \\
\hline Article history: \\
Received: July 162019 \\
Received in revised format: July \\
282019 \\
Accepted: September 2, 2019 \\
Available online: \\
September 2, 2019 \\
\hline Keywords: \\
Loan to Deposits Ratio \\
Regional Economy \\
Market Structure
\end{tabular}

\begin{abstract}
A B S T R A C T
The speed of mobility of public funds by the banking sector implies the conditions of economic liquidity and internal bank liquidity. The faster the mobility of funds, the more the availability of liquidity for the community, the higher banking profitability, and the lower bank's internal liquidity. The uncontrolled mobility of funds can have severe consequences for both banks and society. As an intermediary financial institution, banking plays the main role to be the intermediary institution between surplus units and deficit units. This study aims to find out the factors influencing funds mobilization by Regional Development Bank (RDB) in Indonesia. The data research is quarterly financial statement secondary data of Indonesian regional banking from 2010 to 2017. There are 26 RDBs as the sample and this research uses regression as the research method. The result shows that regional external economic variables such as GDP, Exchange Rate and Inflation, market concentration, and banking characteristics affected the funds mobilization of Indonesian RDBs. This means the pricing strategy must consider more to external and internal variables of economics. In the future, Indonesian RDBs need to develop specific deposits and credits products to maintain and increase the mobilization of funds function.
\end{abstract}

\section{Introduction}

The mobilization of funds is associated with some challenges and risks both from internal and external sources. The mobilization of funds is heavily influenced by some factors such as trust, expectation, security, timeliness, flexible service, and prudent fund management. In addition, fund mobilization also poses risks such as liquidity risk, interest rate risk, credit risk, and capital risk. These risks are the consequence of the reaction of the banking management behavior in its reaction to changes in external conditions as well as the internal development of the bank itself. Bank that has a high non-performing loan will have an impact on crisis and it has potential to disrupt the financial system and may result in financial crisis (Mankiew, 2014). Therefore, the risk mitigation is a priority for every banker to maintain bank stability in order to keep banking in stable circumstance. In a healthy economy, financial institutions should become the intermediary institutions that efficiently mobilize funds from surplus units to deficit units (Mishkin \& Eakins, 2012). Therefore, in the economic system, the primary role of banks and financial institutions is to implement the task of mobilizing public funds by operating their intermediary functions to make efficient relationships between supplier units and DU (deficit units). Banks as the largest element in the financial system in mobilizing funds are given special permission to raise public funds and redistribute in the form of loans or credit to real business sectors. Thus, the main task system of the financial or banking sector is to play an agent role in order to accelerate development and encourage economic growth to improve the economic welfare. The role of banking in mobilizing public funds is not an easy task because of the dynamics of uncertain economic conditions, a rapid regulatory change, intense banking competition, and other circumstances that force bankers to be very careful about the collection and distribution of their funds. A credit disbursement is not only oriented to profit but should further think and lead to efforts to improve the economic welfare. In accelerating the fund mobilization, bankers are required to perform optimally. They should make the funds that can be purchased at relatively low cost. This is a challenge because there is a tight regulations and competition between banks. The acceleration level of funds mobilization can be represented by the development of deposits and loan. If loan to deposit ratio (LDR) increases, it means the speed of mobilization of funds also increases.

* Corresponding author.

E-mail address: sapto.jumono@esaunggul.ac.id (S. Jumono) 
Table 1

Assets Market Share of Indonesian Banking During 2013-2017

\begin{tabular}{|c|c|c|c|c|c|c|}
\hline Group & 2013 & 2014 & 2015 & 2016 & 2017 & Average \\
\hline State-owned Banks & $35.50 \%$ & $36.98 \%$ & $37.72 \%$ & $39.62 \%$ & $40.43 \%$ & $38.05 \%$ \\
\hline Foreign Exchange Banks & $39.61 \%$ & $39.18 \%$ & $38.54 \%$ & $39.71 \%$ & $40.13 \%$ & $39.43 \%$ \\
\hline Non-Foreign Exchange Banks & $3.28 \%$ & $3.33 \%$ & $3.15 \%$ & $1.09 \%$ & $1.19 \%$ & $2.41 \%$ \\
\hline Regional Development Banks & $7.87 \%$ & $7.85 \%$ & $7.76 \%$ & $7.87 \%$ & $8.19 \%$ & $7.91 \%$ \\
\hline Joint Venture Banks & $5.86 \%$ & $4.96 \%$ & $5.11 \%$ & $4.74 \%$ & $4.49 \%$ & $5.03 \%$ \\
\hline Foreign Banks & $7.88 \%$ & $7.70 \%$ & $7.72 \%$ & $6.96 \%$ & $5.57 \%$ & $7.17 \%$ \\
\hline Total & $100 \%$ & $100 \%$ & $100 \%$ & $100 \%$ & $100 \%$ & $100 \%$ \\
\hline Total (Million, IDR) & 4.954 .467 & 5.615 .419 & 6.132 .583 & 6.729 .798 & 7.387 .633 & \\
\hline Assets Growth & & $11.77 \%$ & $8.43 \%$ & $8.87 \%$ & $8.91 \%$ & \\
\hline
\end{tabular}

LDR reflects the ability of banks to extend credit and collect public funds. The higher LDR means the bank optimally do the intermediation function. LDR reflects the bank's ability to provide credits and raise public funds. During the period 20132017, the assets of Indonesian banking continued to increase with the average growth of 9.5\% (See Table 1). The proportion of the majority of assets is controlled by state-owned banks (38.05\%) and foreign exchange banks (39.43\%). Meanwhile, regional development banks owned at $7.91 \%$, non-foreign exchange banks owned at $2.41 \%$, foreign banks owned at $7.17 \%$, and joint-venture banks owned at 5.03\%. The data shows an imbalance in the banking asset market. The structure of the banking market is concentrated in state-owned banks and foreign exchange banks meanwhile the other banks are only market followers.

Table 2

Loan to Deposits Ratio of Indonesian Banking During 2013-2017

\begin{tabular}{lccccc}
\hline \multicolumn{1}{c}{ Group } & 2013 & 2014 & 2015 & 2016 & 2017 \\
\hline Commercial Banks & $89.700 \%$ & $89.420 \%$ & $92.110 \%$ & $90.700 \%$ & $90.040 \%$ \\
State-owned Banks & $86.700 \%$ & $83.730 \%$ & $88.580 \%$ & $88.690 \%$ & $88.670 \%$ \\
Foreign Exchange Banks & $83.770 \%$ & $85.660 \%$ & $87.550 \%$ & $84.830 \%$ & $86.060 \%$ \\
Non-foreign Exchange Banks & $85.100 \%$ & $87.810 \%$ & $81.120 \%$ & $88.370 \%$ & $92.490 \%$ \\
Regional Development Banks & $\mathbf{9 2 . 3 4 0 \%}$ & $\mathbf{8 9 . 7 3 0 \%}$ & $\mathbf{9 2 . 1 9 0 \%}$ & $\mathbf{9 3 . 6 5 0 \%}$ & $\mathbf{8 7 . 6 2 0 \%}$ \\
Joint Venture Banks & $122.200 \%$ & $123.610 \%$ & $132.770 \%$ & $129.010 \%$ & $129.020 \%$ \\
Foreign Banks & $130.050 \%$ & $140.040 \%$ & $131.490 \%$ & $122.380 \%$ & $122.330 \%$ \\
\hline
\end{tabular}

The indicator of funds mobilization which is represented by LDR. Based on the table, the average percentage of LDR is at $90 \%$. This shows that distributed funds are smaller than the collected funds. Joint-venture banks and foreign banks show that their LDRs exceeds $100 \%$, this means the credit given to public exceeds the funds collected. This is interesting to be investigated the factors that influence it. Therefore, it can be detected for further consideration decision-making to manage an efficient banking industry. Although the asset of banking regional development bank (RDB) only amounted to $7.91 \%$ of the national banking assets, however the development of RDP assets is still very possible in terms of demographic factors. RDB is the host of every province in Indonesia, therefore the majority ownership shares are owned by the local provincial government. RDB is more potential mobilizing public funds, especially to support the financing of infrastructure development and SMEs. The financial health indicator of RDB group also shows that RDBs are in healthy condition. The capital adequacy ratio (CAR) exceeds the healthy criteria, which is more than $8 \%$. Meanwhile, return on assets (ROA) of RDBs are all above $1.5 \%$. Even though ROA is decreased, whoever the number is still quite high. The cost efficiency which is represented by cost to income ratio (CIR) shows that RDBs are efficient, the percentage is under $79 \%$.

Table 3

Performance Indicator of Regional Development Banks During 2013-2017

\begin{tabular}{|c|c|c|c|c|}
\hline \multirow[b]{2}{*}{ Tahun } & \multicolumn{4}{|c|}{ Performance Indicator } \\
\hline & CAR & ROA & CIR & SPREA \\
\hline 2013 & $17.58 \%$ & $3.18 \%$ & $73.49 \%$ & $7.04 \%$ \\
\hline 2014 & $17.79 \%$ & $2.68 \%$ & $78.08 \%$ & $6.65 \%$ \\
\hline 2015 & $20.61 \%$ & $2.40 \%$ & $79.57 \%$ & $6.66 \%$ \\
\hline 2016 & $21.69 \%$ & $2.58 \%$ & $78.08 \%$ & $7.07 \%$ \\
\hline 2017 & $21.65 \%$ & $2.40 \%$ & $78.65 \%$ & $6.42 \%$ \\
\hline
\end{tabular}

Source: Indonesian Banking Statistic

There are several studies about mobilization of funds. Tomak (2013) discussed the determinants of commercial credit loans of private banks and state banks in Turkey. The result shows that the bank size, total liabilities, non-performing loans, and inflation had significant effects on commercial credit business while, gross domestic product (GDP) and interest rate had no significant effects on credit business. Buchory's (2014) studied the implementation of intermediation role of RDB and the intermediation role was represented by LDR. The result shows return on assets had significant effect on LDR. The general condition of banking, the factual phenomenon of RDBs, and the gaps of findings from previous relevant research motivate this study to find out the factors influence the development of fund mobilization conducted by Indonesian RDBs. Thus, this study aims to determine the factors that affect the LDR in terms of external factors and internal factors. The external factors are the regional economic conditions, which are GDP-regional, consumer price index (CPI)-regional and Exchange Rate- 
regional, and the structure of national banking market. Meanwhile, the internal factors are NPL, OC/TA ratio, TE/TA ratio, ROA, and NII/TA ratio which are defined in this paper.

\section{Literature review}

Theoretically, the linkage of mobilization of public funds with internal and external factors can be seen if banking is seen as a system. The banking system that is part of the financial system works in the economic system in society. The bank as the largest element of the financial system seeks to optimize its performance by following the dynamics of changing basic economic conditions and market structure (external factors), then the bank exploits these changes by adjusting to its internal conditions to achieve equilibrium. The interaction between the internal banking condition and external factors can be both directional and causality. According to the theory of SCP (structure conduct performance) there is a relationship between BC (Basic condition), S (market structure), $\mathrm{C}$ (conduct) and $\mathrm{P}$ (performance) and bank direction. This means bank performance is a function of external conditions and behavior structure affects behavior and behavior also affects performance, which makes the market inefficient, indicative of collusion, while ESH theory actually states that the relationship between S, C and $\mathrm{P}$, is not only direction but causality: It can mean that in an efficient market it is performance that becomes a function of behavior and market structure. The theory of financial intermediation states that financial intermediation is based on minimizing the cost of production of information to solve incentive problems. The costs incurred by the bank (intermediary) receive the delegation from the owner of the funds to monitor the funds lent to the debtor. This has advantages in terms of cost in collecting information, because this alternative is the activity of each bank so it is more profitable when compared with the owner of the funds to monitor directly. As an intermediary institution, the intermediary function is measured by comparison between the amount of third-party funds that can be collected by the amount of credit or financing disbursed or otherwise known as LDR (Ascarya \& Yumanita, 2010). To describe the relationship between the performance of mobilization of public funds by, here are the results of literature studies from previous studies.

\subsection{The Relationship Between ROA and LDR}

The bank that has a high operational profit will make management increase the mobility of funds, which means the bank will increase the credit obtained from the funds collection from public. Profitability is represented by return on assets (ROA), which is a profitability ratio that describes company's ability to generate profits from every asset used. A high ROA indicates the banks have operating profit more than assets. In this study, return on assets (ROA) is used as a proxy for bank profitability. Some studies of the effect of profitability on fund mobilization (loan to deposits ration) have different results. Vodova (2013) shows that ROA has a significant and positive effect on liquidity. While the research of El-Mehdi and Abderrassoul (2014) and Moussa (2015) found that ROA actually had a significant negative impact on bank liquidity. Another study by Malik and Rafique (2013) found that ROA does not affect LDR.

\subsection{The Relationship Between NPL and LDR}

The banks which have a low non-performing loan (NPL) indicates they also have a low credit risk. This condition encourages banks to increase the volume of loans obtained from public funds. The high bad credit management will decrease the bank liquidity. Non-performing loans causes a loss of income opportunity from the credit, it reduces profits and the ability of banks to provide credit, particularly to pay bank liabilities to depositors. The high level of NPL will make bank be more selective in distributing credits because non-performing loans reduces the value of LDR. Sarath and Pham (2015) stated NPL (non-performing loan) is commonly used to measure credit risk and the quality of a bank loan portfolio. Rose and Hudgins (2013) stated bad credit refers to loans whose loan payments are scheduled to have passed more than 90 days and no longer produce interest income for the bank. Chernykh and Theodossiou (2011) stated bad credit tends to move negatively with commercial bank loans because high bad credit tends to have a riskier bank loan portfolio where banks must allocate more loan losses to bear the risk of default. Amidu (2014) for this reason banks with high NPLs will hinder the pace of credit growth to the public.

\subsection{The Relationship Between Spread and LDR}

The high net interest income will make banking management more enthusiastic to increase the mobility of funds. The bank will encourage people to save more so that the ability of banks to extend credit also increases. Spread-rate is used to measure the bank's management capability in managing its earning assets to generate net interest income. The volume of loans provided greatly affects the bank's profit through interest income. If interest income is high, the bank's profit is also predicted to increase so it can affect bank liquidity. The amount of interest income depends on the amount of credit volume provided. The results from Buchory (2014) found out that spread has a positive and significant effect on bank liquidity. The increase in spread rate will make higher concentration on banking industry, which will cause a decrease in the volume of liquid assets held by banks (Vodová, 2012). In addition, spread which is the difference between the lending rate and deposit rate will be a measure as the opportunity cost for holding liquid assets.

\subsection{The Relationship Between OC/TA with LDR}

The ratio of OC/TA describes the amount of overhead-cost compared to the total assets of the bank. The concept of overhead cost still is different between banking practitioners. Ideally, all costs (excluding interest costs) incurred by the bank in performing its activities are supposed to be calculated as overhead cost. Moreover, there is a concept stating that all costs of funds beyond the cost used in collecting funds and the costs incurred in the management of credit disbursement should be calculated as overhead cost. Therefore, earning asset is assumed to bear the cost. If overhead cost increases, it means that all the banking 
activities including fund mobilization activities will increase. For example, technology will raise overhead cost but the bank is expected to be more efficient. In this study, we will use OC / TA (overhead-cost / total assets) ratio to measure the efficiency of bank overhead-costs, this ratio is used by several empirical studies similar to (Zedan \& Dass, 2017).

\subsection{The Relationship Between TE/TA and LDR}

The high capital increases the bank's solvency which also will raise the banking trust and encourage people to make deposit. In the end, the banking credit distribution will also be high. In our study, we use the ratio of total equity to total assets (TE / TA) for the calculation of the capital adequacy ratio. In relation to fund mobilization, several findings show that the capital ratio has a positive impact on the LDR (e.g. Vodova, 2013; El-Mehdi \& Abderrassoul, 2014). While Melese (2015) and Moussa, (2015) reported that capital had a negative impact on the LDR and Research Malik and Rafique (2013) found no significant impact on LDR.

\subsection{The Relationship Between Market Concentration and LDR}

Market concentration can be interpreted as a percentage of market share dominated by relatively large companies to the total market share. Concentration is not caused by accidental factors but it is caused by the permanent forces that lie behind the concentrations that usually do not change much over time. Concentration also indicates the level of production of a market or industry that focuses only on one or a few largest companies. Concentration is the number of market shares of reputable companies or oligopolists, whereby the companies are aware of the interdependence of each other. If market conditions become more concentrated, the market is increasingly monopolized, and the competition is decreasing. The ability of mobilization of funds by the follower decreases, this may not be true if the follower bank has certain capabilities/advantages in expanding the market, they penetrate new market to increase mobility of public fund, bank will increase financial inclusive so that society save more and bank ability to distribute credit also increased.

\subsection{The Relationship Between Exchange Rate and LDR}

If a country's exchange rate increases, the currency of the country becomes more valuable, the banking profitability rises and economic liquidity becomes higher, whereas if a country's exchange rate decreases, it means that the currency becomes worthless and can cause loss of profitability and liquidity. While Bruno and Shin (2015) indicated that if the effective real exchange rate increases (for example due to appreciation of the local currency or depreciation of the US dollar), loans by local banks from global banks will increase at the aggregate level and cross-border flows will increase. This will have the same effect as decreasing credit risk. If the domestic currency exchange rate is depreciated, then the value of bank asset in the form of the domestic currency will decrease. This can make interest rates rise and the acceleration of mobilization of public funds to go down. The opposite may happen if the interest rate set by the bank already includes exchange rate risk, therefore if the exchange rate of domestic currency depreciates the bank does not need to raise the interest rate so that the mobilization of public funds will increase. According to Brunnermeier and Pedersen (2009) the interaction between funding and market liquidity causes a liquidity spiral. Acharya and Viswanathan (2011) found a relationship between funding, liquidity and assets pricing. According to them, when financial companies use short-term debt to finance asset purchases, negative asset shocks force the company to leverage, causing market and funding liquidity to decline.

\subsection{The Relationship Between Inflation and LDR}

If inflation occurs, the value of bank's assets in the form of the domestic currency will decrease. This could make bank interest rates raise and the achievements of banks in the mobilization of public funds are going down. Bank managers succeed in providing more loans as long as inflation is low volatility due to expected returns that can be predicted. In contrast, bank lending managers tend to be more conservative during the inflation phase because expected returns are unexpected. Inflation rate will positively affect the overall liquidity of the bank. Chagwiza (2014) which stated the growth rate of the inflation rate has a significant positive impact on bank liquidity.

\subsection{The Relationship Between GDP and LDR}

The relationship between GDP and LDR is in accordance with the theory of money demand. If GDP rises, it means income society rises, therefore demand for money for transactions and the ability of people to save also increases. When the income of society is high, then bank deposits will also increase which make the increment of the ability of banks in distributing credits. Economic growth is an important factor that influences bank loans, because the high level of economic growth reflects the high rate of economic activity in the country so that it will indirectly increase demand for money. This study will follow a previous study by using the annual percentage change in GDP (constant-price) as a proxy to investigate the relationship between economic conditions and fund mobilization by commercial banks as done by Mousa and Chedia, (2016); Sarath and Pham, (2015); Rabab'ah (2015). GDP growth is expected to have a positive influence with fund mobilization proxied by the LDR and the result is in accordance with the result of Chagwiza (2014).

\section{Research model}

\subsection{Data and Research Variables}

This study is an applied research because the purpose of this study is to apply the previous research method and then it will be developed theoretically. This research is also an explanatory research because this study also aims to explain the causal relationship between variables through hypothesis testing. The object of this research is banking market industry in Indonesia. 
While the subject of research is RDBs (Regional Development Bank). This research observes the development of the regional economy, market structure, banking characteristics, and the research focus is the banking liquidity. The data used is secondary data from published financial statements of the Central Bank of Indonesia, World Bank, and Indonesian Banking Statistics (IBS) for the period 2010-2017, quarterly data. The population is all regional development banks which operates in Indonesia from 2010 to 2017. The sample is saturation sample which consists of 26 Indonesian regional development banks.

\subsection{Model Specification}

To create patterns of influence of regional economic conditions, market structure and banking characteristics on funds mobilization, the econometric model as follows,

$$
L D R_{i t}=\alpha_{0}+\alpha_{1} R O A_{i t}+\alpha_{2} N P L_{i t}+\alpha_{3} \text { Spread }_{i t}+\alpha_{4} O C T A_{i t}+\alpha_{5} T E T A_{i t}+\alpha_{6} C R 4 A_{t}+\alpha_{7} E R r_{i t}+\alpha_{8} I_{n f} r_{i t}+\alpha_{9} G D \operatorname{Pr}_{i t}+e_{i t}
$$

where $i$ indicates individual bank while $t$ is period of quarter in certain year; LDR $=$ loan to deposit ratio. The LDR is an indicator to measure the fund mobilization of banks. A higher LDR implies a lower intermediation banking; $\mathrm{CR} 4-\mathrm{A}=\mathrm{Con}-$ centration ratio; ER-r = regional exchange rate; CPI-r = regional consumer price index; GDP-r = regional gross domestic product; NPL = non performing loan or credit risk; ROA = return on total assets; TE/TA = equity to assets Ratio; Spread = NII (net interest income) proportion in total assets, and OC/TA = proportion of overhead of total assets.

\subsection{Research Variables}

The variables of internal factors and external factors refer to previous theories and research. The internal factors are banking specific characteristics (Athanasoglou et al., 2008). Banking specific characteristics are factors derived from the internal condition of the bank, which can be seen from the financial ratios in the balance sheet and earnings report bank loss.

\section{Table 4}

Operational Definition Variables and Their Measurements

\begin{tabular}{|c|c|c|c|c|c|c|}
\hline \multicolumn{4}{|c|}{ Variable } & $\begin{array}{l}\text { Measurement/ } \\
\text { Formula }\end{array}$ & Notation & \multirow[t]{2}{*}{ Impact } \\
\hline & Dependent Variable & Fund Mobilization & $>$ Loan to Deposit Ratio & - $\quad($ Loan/Deposit $) \times 100 \%$ & LDR & \\
\hline \multirow[t]{9}{*}{$\begin{array}{c}\text { Determinant } \\
\text { (Independent } \\
\text { Variable) }\end{array}$} & $\begin{array}{l}\text { Internal } \\
\text { banking }\end{array}$ & $\begin{array}{l}\text { Profitability, Assets } \\
\text { Capital, Cost \& } \\
\text { Revenue }\end{array}$ & $\begin{array}{l}>\text { Return on Assets } \\
>\text { Non Performing Loan } \\
>\text { Spread rate }\end{array}$ & $\begin{array}{ll}\text { - } & (\mathrm{NOI} / \mathrm{TA}) \times 100 \% \\
\text { - } & (\mathrm{NPL} / \mathrm{Total} \text { Loan })\end{array}$ & ROA & + \\
\hline & & Management & $\begin{array}{l}>\text { Overhead cost Ratio } \\
>\quad \text { Capital }\end{array}$ & $\begin{array}{ll} & \times 100 \% \\
\text { - } \quad(\text { NII } / \text { Total Assets }) \times 100 \%\end{array}$ & NPL & - \\
\hline & & & & & Spread & + \\
\hline & & & & $\begin{array}{l}\text { - (Equity/Total Assets }) \times \\
100 \%\end{array}$ & OC/TA & - \\
\hline & & & & & TE/TA & + \\
\hline & $\begin{array}{l}\text { Market } \\
\text { Structure }\end{array}$ & $\begin{array}{c}\text { Market } \\
\text { Competition }\end{array}$ & $\begin{array}{l}\text { Market Concentration of } \\
\text { Assets }\end{array}$ & $\begin{array}{l}\text { The } 4 \text { largest total market } \\
\text { share assets in the banking } \\
\text { assets market (\%) }\end{array}$ & CR4A & - \\
\hline & $\begin{array}{l}\text { Macro } \\
\text { Economy }\end{array}$ & $\begin{array}{l}\text { Exchange Rate } \\
\text { Inflation, }\end{array}$ & $\begin{array}{l}>\text { Exchange Rate-regional } \\
>\text { Inflation -regional }\end{array}$ & - Rupiah/USD & ER-r & - \\
\hline & & Economy Activity & $>$ GDP-regional & $\begin{array}{l}\text { - } \quad(\text { CPIt-CPIt-1)/CPIt-1 } \\
\times 100\end{array}$ & Inf-r & - \\
\hline & & & & - GDR-riil (Constant Price) & GDP-r & + \\
\hline
\end{tabular}

\section{Data analysis and discussion}

To make inferential analysis, this research is performed by making three models of panel data regression i.e. OLS (Ordinary Least Square) model, FE (Fixed Effect), and RE (Random Effect). After that, we select the best among the three models by using Chow test to choose between OLS model with FE model; Hausman's test to choose between FE model and RE model, and LM (Lagrange Multiplier) to choose between OLS or RE models. Chow test results show that prob-F $=0.0000<0.05$, which means that the model selected is the FE model. Hausman test shows prob-F value $=0.06>0.05$, which means the model chosen is RE model. The LM test shows the prob-F value $=0.0000<0.05$ which means the model chosen is the RE model. Therefore, from the model selection test it is evident that the suitable or appropriate model is the RE model. The RE model as the best model needs to be tested BLUE via post estimation test. To find out whether the selected RE model meets the BLUE criteria or not, multicollinearity and autocorrelation tests are required. The multicollinearity test results show a VIF (Variance Inflating Factor) of 32.65 $>10$; which means there are indications of multicollinearity. While the Autocorrelation test shows prob-F $=0.0002<0.05$, there is an indication of autocorrelation. So, RE does not meet the qualification of BLUE test. Therefore, we need to look for the alternative models. In this research, the alternative chosen model is GLS (Generalized Least Square).

\subsection{Discussion}

Based on Table 3, the GLS model shows that the mobilization of public funds by RDBs which is represented by LDR is influenced by macroeconomic factors, market structure, and banking characteristics. This means the systemic development of mobilization of public funds by Indonesian RDBs is related to regional macroeconomic conditions such as GDP-r, CPI-r and ER-r; the structure of the national banking asset market (CR4-A) and the bank's internal conditions such as NPL, Spread, ROA and TE/TA ratio. 
Table 3

The Factors Influence Fund Mobilization (Loan to Deposits Ratio) in Indonesian RDBs

\begin{tabular}{|c|c|c|c|c|}
\hline \multirow{2}{*}{$\begin{array}{c}\text { Independent } \\
\text { Variable }\end{array}$} & \multicolumn{4}{|c|}{ Model } \\
\hline & FE & $\mathbf{R E}$ & OLS & GLS \\
\hline NPL (Non performing loan) & $-1.2158 * * *$ & $-1.2158 * * *$ & $-1.2158 * * *$ & $-1.2158 * * *$ \\
\hline SPREAD (Spread-rate) & $5.4878 * * *$ & $5.4878 * * *$ & $5.4878 * * *$ & $5.4878 * * *$ \\
\hline OC/TA (overhead cost) & 0.60486 & 0.60486 & 0.60486 & 0.60486 \\
\hline ROA (Return on assets) & $-3.5476 * * *$ & $-3.5476 * * *$ & $-3.5476 * * *$ & $-3.5476 * * *$ \\
\hline TE/TA (total equity/total asset) & $1.1550 * * *$ & $1.1550 * * *$ & $1.1550 * * *$ & $1.1550 * * *$ \\
\hline CR4-A (concentration of assets) & $84.5837 * *$ & $84.5837 * *$ & $84.5837 * *$ & $84.5837 * *$ \\
\hline ER-R (Exchange rate-Region) & $0.00124 * * *$ & $0.00124 * * *$ & $0.00124 * * *$ & $0.00124 * * *$ \\
\hline CPI-R (Inflation-Regional) & $0.04027 *$ & $0.04027 *$ & $0.04027 *$ & $0.04027 *$ \\
\hline GDP-R (GDP-Regional) & $1.501 \mathrm{e}-08 * *$ & $1.501 \mathrm{e}-08 * *$ & $1.501 \mathrm{e}-08 * *$ & $1.501 \mathrm{e}-08 * *$ \\
\hline cons & -20.6565 & -20.6565 & -20.6565 & -20.6565 \\
\hline $\mathrm{F}(9,791) /$ Wald $\operatorname{chi}^{2}(9)$ & 50.380 & 449.08 & 41.650 & 379.57 \\
\hline Prob $>$ F $/$ Prob $>$ chi $^{2}$ & 0.0000 & 0.0000 & 0.00000 & 0.0000 \\
\hline R-sq: within & 0.3718 & 0.3711 & & \\
\hline between & 0.0886 & 0.1384 & & \\
\hline overall & 0.2845 & 0.3034 & & \\
\hline R-squared & & & 0.3215 & \\
\hline Adj R-squared & & & 0.3138 & \\
\hline Number of obs & 801 & 801 & 801 & 801 \\
\hline Number of groups & 26 & 26 & 26 & 26 \\
\hline Obs per group: $\min$ & 30 & 30 & 30 & 30 \\
\hline Avg & 30.8 & 30.8 & 30.8 & 30.8 \\
\hline Max & 31 & 31 & 31 & 31 \\
\hline OLS/RE $: \operatorname{chi}^{2}(1)$ & & 514.34 & & \\
\hline Prob $>$ chi $^{2}$ & & 0.0000 & & \\
\hline OLS/FE : F(25, 766) & 10.830 & & & \\
\hline Prob $>F$ & 0.0000 & & & \\
\hline $\mathrm{FE} / \mathrm{RE}: \operatorname{chi}^{2}(8)$ & & 14.920 & & \\
\hline Prob $>\mathrm{chi}^{2}$ & & 0.0606 & & \\
\hline Multicol test / Mean VIF & & 32.65 & & \\
\hline Autocorr test $/ \mathrm{F}(1,25)$ & & 18.513 & & \\
\hline Prob $>$ F & & 0.0002 & & \\
\hline
\end{tabular}

\subsubsection{The Effect of NPL on $L D R$}

In general, bad credit tends to move negatively with commercial bank loans because banks with high bad credit tend to have a riskier bank loan portfolio where banks must allocate more loan loss provisions to risk default. The results of the analysis show NPL (Non-performing loan) has a significant and negative effect to LDR. This is a good condition because a low NPL indicates smaller credit risk which makes bank increase the allocation of credit. This is consistent with Amidu's research, which states that banks with high NPLs will hinder the rate of credit growth to the public (Amidu, 2014), in accordance with the flow of thought of Chernykh and Theodossiou, (2011).

\subsubsection{The Effect of Spread on LDR}

The spread rate variable has a significant positive effect on LDR which means the greater net interest margin will also make the greater LDR. This indicates bank has managed to optimize the difference between interest income and interest expenses from total assets operated by bank. The optimal net interest margin drives to increase LDR. The result is in accordance with the findings from Buchory (2014) which found out that spread had a significant positive effect on bank liquidity. This finding is also in accordance with Vodová (2013), which shows that the increase in spread rate tends to improve their borrowing function, which in turn can cause a decrease in the volume of liquid assets held by banks (internal liquidity bank, decrease).

\subsubsection{The Effect of ROA on LDR}

Return on assets has a significant negative effect on LDR which means a low ROA will make a high LDR. This does not literally mean if a low ROA will make operating profit goes down. Mathematically, a lower ROA occurs because the growth of operational profit is smaller than the growth of asset. Asset growth has an effect on increasing market access which make the bank's ability to attract and distribute fund is getting stronger. The findings of the effect of the loan to deposits ratio are similar to the findings of the study by El-Mehdi and Abderrassoul, (2014) and Moussa (2015), but these findings contradict with Vodova, (2013) addressing ROA has a significant positive effect on liquidity (LDR).

\subsubsection{The Effect of TETA on LDR}

A high capital adequacy ratio can provide a large space internally and externally for banks because the adequacy of banks capital is a requirement of safe regulations. The higher capital adequacy will make an optimal an intermediary function of banks in this case the credit distribution. In this research, the ratio of TE/TA has a significant and positive effect on LDR which means the high capital will increase LDR. Increasing the capital of banks to make the solvency of banks increases, this influences on trust society ability of banks to collect public funds and channeled back to the community in the form of credit 
becomes increasingly rising. The findings are in accordance with the research findings of Vodova (2013) and El-Mehdi and Abderrassoul's (2014) which showed that capital ratios had a positive impact on the LDR. However, this finding contradicts with the research of Moussa (2015).

\subsubsection{The Effect of Concentration on $L D R$}

CR4-A variable is the level of assets market power of the four largest banks. The result shows that concentration has a significant and positive effect on LDR which means that the direction of the national banking assets market structure is in line with the development of funds mobilization by RDBs. This is reasonable because RDBs are one of the parts of national banking system. It only has small market share so it becomes market follower. Therefore, funds mobilization of RDBs is affected by the dynamics of the national banking market structure. There is a positive effect of CR4-A (accumulation of the four largest National bank assets) on the dynamics of fund mobility in each province in the regional bank in Indonesia. The mobility of funds by regional banks is in line with the national banking structure. The speed of mobilization of public funds carried out by regional banking follows the dynamics of the national banking market structure.

\subsubsection{The Effect of Exchange Rate on LDR}

According to Brunnermeier and Pedersen (2009) the interaction between funding and market liquidity causes a spiral of liquidity. While Acharya and Viswanathan (2011) found a relationship between bank funding, liquidity and asset prices. According to them, when financial companies use short-term debt to finance asset purchases, negative asset shocks force the company to leverage, causing market and funding liquidity to decline. The trend of Rp/USD currency of regional-province has a positive effect on LDR. This means the dynamics of forex market has a role in the rise of the turmoil of the RDBs' capability in mobilizing funds. Banking management succeeded in utilizing the depreciation of rupiah to keep increasing LDR. This result supports the research from Mongid (2008) which suggests that exchange rate has a significant positive effect on the provision of credit.

\subsubsection{The Influence Inflation on LDR}

The regional inflation which represents the development of provincial market output prices has a significant and positive influence on LDR. This means that price development in the regional goods/services market plays a significant role of RDBs' capability in mobilizing funds. A high CPI will support RDBs in mobilizing funds. This is because the banking management managed to anticipate the impact of inflation in pricing strategy to keep increasing LDR. Chagwiza (2014) stated the inflation rate has a significant positive impact on bank liquidity.

\subsubsection{The Influence of GDP on $L D R$}

The GDP-R variable or regional gross domestic product development progresses has a significant and positive influence on LDR. This means the regional output market condition contributes to the rise of the turmoil on the mobilization capability of RDBs' funds. The greater the regional economic activity means better people's income so this encourages people to be able to save, on the other hand the demand for public money also rises, especially the demand for money for transactions. Therefore, the access to BPD in collecting and channeling funds is increasing. This finding is in accordance with Moussa and Chedia's research, (2016); Sarath and Pham, (2015); Rabab'ah, (2015), there is an influence of economic conditions on liquidity or fund mobilization by commercial banks. GDP growth has a positive influence with fund mobilization proxied by the LDR, the result is in accordance with Chagwiza (2014) which shows that the growth rate of GDP has a significant positive impact on bank liquidity.

\section{Conclusions and Implications}

\subsection{Conclusion}

The funds mobilization of RDBs in all provinces in Indonesia is influenced by external factor of internal banking. The external factors consist of regional GDP, regional exchange rate, regional inflation and national banking concentration. They have significant and positive effect of loan to deposit ratio. Meanwhile, the internal banking factors that have significant positive effect are spread rate and TE/TA. The variable which has a negative significant effect is non-performing loan and return on assets. This indicates that bank operations in Indonesian RDBs is systematically working to optimize the rotation of funds, the funds mobilization is affected by changes in regional economic conditions and the structure of the national banking market. Therefore, the RDBs need to mitigate the risk. Moreover, the utilization and anticipation of the opportunities and threats sourced from these external factors need to be oriented in long term perspective without neglect on short term interests especially in managing the health aspects of profitability, capital, interest rate spread, earning assets and cost-revenue management.

\subsection{Implications}

The implementation of intermediation role of RDBs by increasing the effectiveness of funds mobilization can be enhanced to prioritize management pricing. Net interest income can be increased by increasing the volume of third-party fund and loan by making loan growth bigger than third party fund growth. It also can be increased by arising financial inclusive to penetrate and explore new potential market but it still should consider the prudential aspect to reduce risk. The effectiveness of fund mobilization can also be done by developing specific banking products; therefore, the customers will become loyal. The product development is not only focused on credit and deposit market, but it is also important to develop fee-based income- 
based products. This is important because the future of the market will be more competitive so that the spread-rate must be thinning. The development of fee-based income products is an alternative to maintain the stability of bank revenue. It is important to prioritize and upgrade EWS (early warning system) to anticipate changes in regional macroeconomic conditions and market structure changes, as these external variables are significant to the accelerated mobilization of funds. These external factor changes need to be included in every decision making especially in the pricing strategy which greatly affects the rapid mobilization of public funds by banks.

\section{References}

Ascarya, \& Yumanita, D. (2010). Determinants of Bank's Net Interest margin in Indonesia. International Conference on Eurasian Economies, Central Bank of Indonesia.

Acharya, V. V., \& Viswanathan, S. (2011). Leverage, moral hazard, and liquidity. The Journal of Finance, 66(1), 99-138.

Amidu, M. (2014). What influences banks lending in sub-Saharan Africa?. Journal of Emerging Market Finance, 13(1), 142.

Athanasoglou, P. P., Brissimis, S. N., \& Delis, M. D. (2008). Bank-specific, industry-specific and macroeconomic determinants of bank profitability. Journal of international financial Markets, Institutions and Money, 18(2), 121-136.

Bruno, V., \& Shin, H. S. (2014). Cross-border banking and global liquidity. The Review of Economic Studies, 82(2), $535-564$.

Brunnermeier, M. K., \& Pedersen, L. H. (2008). Market liquidity and funding liquidity. The Review of Financial Studies, 22(6), 2201-2238.

Buchory, H. A. (2014). Analysis of the effect of capital, credit risk, and profitability to implementation banking intermediation function (Study on Regional Development Bank All Over Indonesia Year 2012). International Journal of Business, Economic, and Law, 4(1), 133-144.

Chagwiza, W. (2014). Zimbabwean commercial banks liquidity and its determinants. International Journal of Empirical Finance, 2(2), 52-64.

Chernykh, L., \& Theodossiou, A. K. (2011). Determinants of bank long-term lending behavior: Evidence from Russia. Multinational Finance Journal, 15(3/4), 193-216.

El-Mehdi, F., \& Abderrassoul, L. (2014). Liquidity Determinants of Moroccan Banking Industry. International Research Journal of Finance and Economics, 118.

Malik, M. F., \& Rafique, A. (2013). Commercial banks liquidity in Pakistan: Firm specific and macroeconomic factors. Romanian Economic Journal, 16(48), 139-154.

Mankiew, N. G. (2014). Principles of Macroeconomics. Seventh Edition. Stanford: Cengage.

Mishkin, F. S, \& Eakins, S. (2012). Financial Market and Institutions Seventh Edition. United State of America: Prentice Hall.

Mongid, A. (2008). The impact of monetary policy on bank credit during economic crisis: Indonesia's experience. Jurnal Keuangan dan Perbankan, 12(1), 100-110.

Moussa, M. A. (2015). The Determinants of bank liquidity: Case of Tunisia. International Journal of Economics and Financial Issues, 5, 249-259.

Mousa, M. A. B., \& Chedia, H. (2016). Determinants of bank lending: Case of Tunisia. International Journal of Finance and Accounting, 5(1), 27-36.

Rabab'ah, M. (2015). Factors affecting the bank credit: An empirical study on the Jordanian commercial banks. International journal of Economics and Finance, 7(5), 166-178.

Rose, P. S., \& Hudgins, S. C. (2013). Bank Management \& Financial Services. he McGraw-Hill Companies.

Sarath, D., \& Pham, D. V. (2015). The determinants of Vietnamese banks' lending behavior: A theoretical model and empirical evidence. Journal of Economic Studies, 42(5), 861-877.

Tomak, S. (2013). Determinants of commercial banks' lending behavior: Evidence from Turkey. Asian Journal of Empirical Research, 3(8), 933-943.

Vodova, P. (2013). Determinants of commercial bank liquidity in Hungary.e-Finanse: Financial Internet Quarterly, 9(3), 6471.

Zedan, K. A., \& Daas, G. (2017). Palestinian Banks Analysis Using CAMEL Model. International Journal of Economics and Financial Issues, 7(1), 351-357.

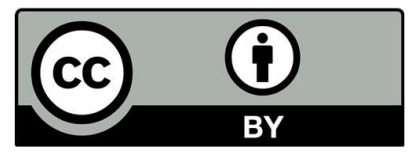

(C) 2020 by the authors; licensee Growing Science, Canada. This is an open access article distributed under the terms and conditions of the Creative Commons Attribution (CCBY) license (http://creativecommons.org/licenses/by/4.0/). 